NATALIA JAŚKIEWICZ

Państwowa Wyższa Szkoła Zawodowa w Nowym Sączu, Polska • State University of Applied Sciences in Nowy Sącz, Poland

\title{
Pozarolnicza przedsiębiorczość indywidualna w gminach subregionu sądeckiego
}

\section{Non-Agricultural Individual Entrepreneurship in Communes of Sądecki Sub-Region}

Streszczenie: Przedmiotem artykułu jest analiza zjawiska pozarolniczej przedsiębiorczości indywidualnej, rozumianej jako podejmowanie i prowadzenie działalności gospodarczej przez osoby fizyczne. Jako miernik tego zjawiska uznano liczbę zarejestrowanych osób fizycznych prowadzących pozarolniczą działalność gospodarczą na 1000 osób w wieku produkcyjnym. Tak skonstruowany miernik jest jednym $\mathrm{z}$ aspektów wchodzących w skład szeroko rozumianego poziomu przedsiębiorczości. Celem przeprowadzonej analizy było zdiagnozowanie poziomu pozarolniczej przedsiębiorczości indywidualnej, rozpoznanie zróżnicowania w czasie i przestrzeni oraz zbadanie związku pomiędzy poziomem pozarolniczej przedsiębiorczości indywidualnej a poziomem bezrobocia oraz poziomem dochodów własnych budżetu gminy. Badaniem objęto subregion sądecki, czyli 39 jednostek terytorialnych szczebla podstawowego, w tym: 38 gmin z 3 powiatów (gorlickiego, limanowskiego i nowosądeckiego) oraz miasto Nowy Sącz. Materiał do badań stanowiły opracowania statystyczne GUS oraz informacje BDL. Diagnozę poziomu pozarolniczej przedsiębiorczości indywidualnej oparto na trzech grupach informacji dotyczących: a) liczby zarejestrowanych osób fizycznych prowadzących pozarolniczą działalność gospodarczą, b) liczby nowo zarejestrowanych osób fizycznych prowadzących pozarolniczą działalność gospodarczą, c) liczby wyrejestrowanych osób fizycznych prowadzących pozarolniczą działalność gospodarczą. Przeprowadzono analizę statystyczną i kartograficzną uzyskanych wyników. Zauważono istotne zróżnicowanie pozarolniczej działalności indywidualnej w gminach subregionu sądeckiego. Stwierdzono m.in., że występuje słaba zależność pomiędzy poziomem badanego zjawiska a poziomem bezrobocia $\mathrm{w}$ danej gminie oraz wysoka zależność pomiędzy poziomem badanego zjawiska a poziomem dochodów własnych gminy.

\begin{abstract}
The subject of the article is an analysis of non-agricultural, individual entrepreneurship understood as undertaking and conducting business activities by natural persons. The measurement of the phenomenon is a number of registered natural persons who conduct non-agricultural business per every 1,000 people of working age. Such constructed standard is one of many aspects which is included in the level of entrepreneurship. The purpose of conducted analysis was to diagnose the level of non-agricultural, individual entrepreneurship, recognise the variety in time and space, as well as studying the relations between the level of non-agricultural, individual entrepreneurship and the level of unemployment and the level of self-income in a commune. The subject of the study was the
\end{abstract}


sądecki sub-region that is 39 territorial units of the basic level including 38 communes from three districts (gorlicki, limanowski and nowosądecki) and the town of Nowy Sącz. Research materials consist of statistical analysis of Central Statistical Office and information from the Local Data Bank. A diagnosis of non-agricultural, individual entrepreneurship level was based on three pieces of information: a) the number of registered natural persons conducting business, b) the number of newly-registered natural persons conducting business, c) the number of deregistered natural persons conducting business. Statistical and cartographic analysis of results obtained was conducted. Significant variety of non-agricultural, individual entrepreneurship in the communes of sądecki sub-region was observed. It was observed that there is a weak dependence between the studied phenomenon and the level of unemployment in a given commune, as well as high dependency between the level of the studied phenomenon and the level of self-income of a commune.

Słowa kluczowe: działalność gospodarcza; gmina; podmioty osób fizycznych; przedsiębiorczość

Keywords: economic activity; entities of natural persons; entrepreneurship; municipality

Otrzymano: 25 października 2017

Received: 25 October 2017

Zaakceptowano: 4 czerwca 2018

Accepted: 4 June 2018

\section{Sugerowana cytacja/Suggested citation}

Jaśkiewicz, N. (2018). Pozarolnicza przedsiębiorczość indywidualna w gminach subregionu sądeckiego. Przedsiębiorczość - Edukacja [Entrepreneurship - Education], 14, 62-79. DOI: $10.24917 / 20833296.14 .5$

\section{Wstęp}

Pojęcie przedsiębiorczości jest wieloaspektowe i brakuje w literaturze zgodności co do jego znaczenia. W ujęciu ekonomicznym przedsiębiorczość jest często traktowana jako czwarty (obok ziemi, kapitału i pracy) czynnik produkcji przejawiający się w obszarze racjonalizacji i twórczego stosowania nowatorskich rozwiązań przynoszących lepsze efekty wykorzystywania pozostałych czynników (Niedziółka, 2010).

Przedsiębiorczość jest zjawiskiem społeczno-gospodarczym. W Polsce jej rozkwit nastąpił od początku lat 90. XX w. Sprzyjały temu warunki stworzone przez gospodarkę rynkową, a szczególnie wprowadzenie zasad demokracji gospodarczej, zakładających swobodę tworzenia i prowadzenia przedsiębiorstw dla wszystkich oraz równe prawa regulujące ich funkcjonowanie (Targalski, 1999).

Według K. Kucińskiego, przedsiębiorczość rozpatrywana na poziomie gminy w kontekście rozwoju lokalnego ma dwa wymiary. Jeden dotyczy przedsiębiorczości władz samorządowych gminy, drugi zaś faktycznie podejmowanej i prowadzonej działalności gospodarczej (Kuciński, 2010). Należy wskazać bądź wyodrębnić z tych dwóch wymiarów jeszcze dwa kolejne, mianowicie: przedsiębiorczość członków lokalnych organizacji prowadzonych w ramach partnerstwa terytorialnego (tzw. lokalnych grup działania) oraz przedsiębiorczość społeczności lokalnej.

Przedmiotem niniejszego artykułu jest analiza zjawiska pozarolniczej przedsiębiorczości indywidualnej, rozumianej jako podejmowanie i prowadzenie działalności gospodarczej przez osoby fizyczne. Pozarolnicza działalność indywidualna jest jednym z elementów (poza działalnością rolniczą i działalnością innych niż firmy osób 
fizycznych podmiotów gospodarczych) drugiego wymiaru, tj. podejmowanej i prowadzonej działalności gospodarczej na danym terenie. Jako wskaźnik określający poziom pozarolniczej przedsiębiorczości indywidualnej przyjęto liczbę zarejestrowanych osób fizycznych prowadzących pozarolniczą działalność gospodarczą na 1000 osób w wieku produkcyjnym.

Analiza została oparta na danych zawartych w Banku Danych Lokalnych GUS (BDL), dotyczących liczby zarejestrowanych, nowo zarejestrowanych i wyrejestrowanych z rejestru REGON podmiotów gospodarki narodowej w części dotyczącej osób fizycznych prowadzących pozarolniczą działalność gospodarczą. Należy zwrócić uwagę na trafność zastrzeżeń dotyczących prawidłowości i kompletności pochodzących z BDL danych, gdyż część firm faktycznie zawiesza bądź zaprzestaje prowadzenia działalności gospodarczej, ale nie ujawnia od razu tego faktu (Kudłacz, Reśko, 2007). Niemniej jednak, odkąd działa tzw. jedno okienko i przedsiębiorcy mają ułatwiony kontakt w korygowaniu wpisów w Centralnej Ewidencji i Informacji o Działalności Gospodarczej, BDL wydaje się być najlepszym źródłem informacji agregującym dane na poziomie lokalnym.

Badanie przeprowadzono w gminach subregionu sądeckiego. Analiza dotyczy okresu od 2012 do 2016 r. Lata objęte badaniem wynikają z dostępności danych zawartych w BDL.

Jako metody badawcze zastosowano: analizy statystyczne rozkładów wskaźnika określającego poziom pozarolniczej przedsiębiorczości indywidualnej, wykresy, analizy kartograficzne oraz badanie korelacji z użyciem współczynnika Pearsona.

Celem przeprowadzonej analizy jest odpowiedź na pytania:

- Jakie jest zróżnicowanie poziomu pozarolniczej przedsiębiorczości indywidualnej w gminach subregionu sądeckiego?

- Czy występuje związek pomiędzy pozarolniczym poziomem przedsiębiorczości indywidualnej a statusem gminy?

- Czy występuje związek pomiędzy poziomem pozarolniczej przedsiębiorczości indywidualnej a poziomem bezrobocia w danej jednostce?

- Czy występuje związek pomiędzy poziomem pozarolniczej przedsiębiorczości indywidualnej a poziomem dochodów własnych gmin?

\section{Charakterystyka subregionu sądeckiego}

Subregion sądecki położony jest w środkowej i południowo-wschodniej części województwa małopolskiego. Większość jego powierzchni zajmują tereny górskie i wyżynne, a także doliny rzeczne. Takie ukształtowanie terenu ma znaczący wpływ na podejmowanie i prowadzenie działalności gospodarczej. Główne skupienie osadnicze subregionu to tzw. Kotlina Sądecka, której warunki klimatyczne i glebowe są korzystne dla rolnictwa, w tym silnie rozwiniętego $\mathrm{w}$ regionie sadownictwa.

Geograficzne rozmieszczenie jednostek objętych badaniem zaprezentowano na rycinach 2, 3 i 4.

Subregion sądecki obejmuje 39 jednostek terytorialnych szczebla podstawowego z 3 powiatów, w tym: 10 jednostek z powiatu gorlickiego, 12 jednostek z powiatu limanowskiego oraz 16 jednostek $\mathrm{z}$ powiatu nowosądeckiego wraz $\mathrm{z}$ miastem na prawach powiatu - Nowym Sączem. Charakterystykę jednostek poddanych badaniu, uszeregowanych ze względu na liczbę ludności w poszczególnych powiatach, zaprezentowano w tabeli 1. 
Ryc. 1. Powiaty w województwie małopolskim

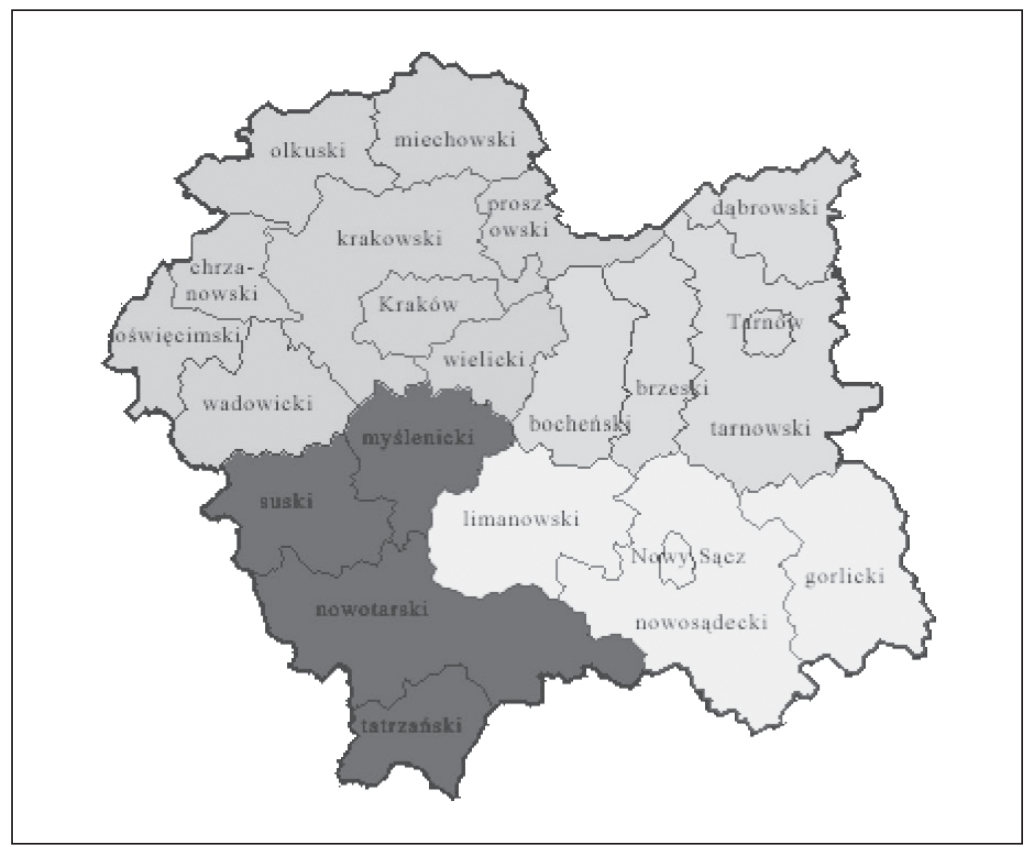

Źródło: http://zasoby-ludzkie.wup-krakow.pl/powiat-1-malopolska.html (data dostępu: 2017, 1 września)

Ryc. 2. Gminy powiatu gorlickiego

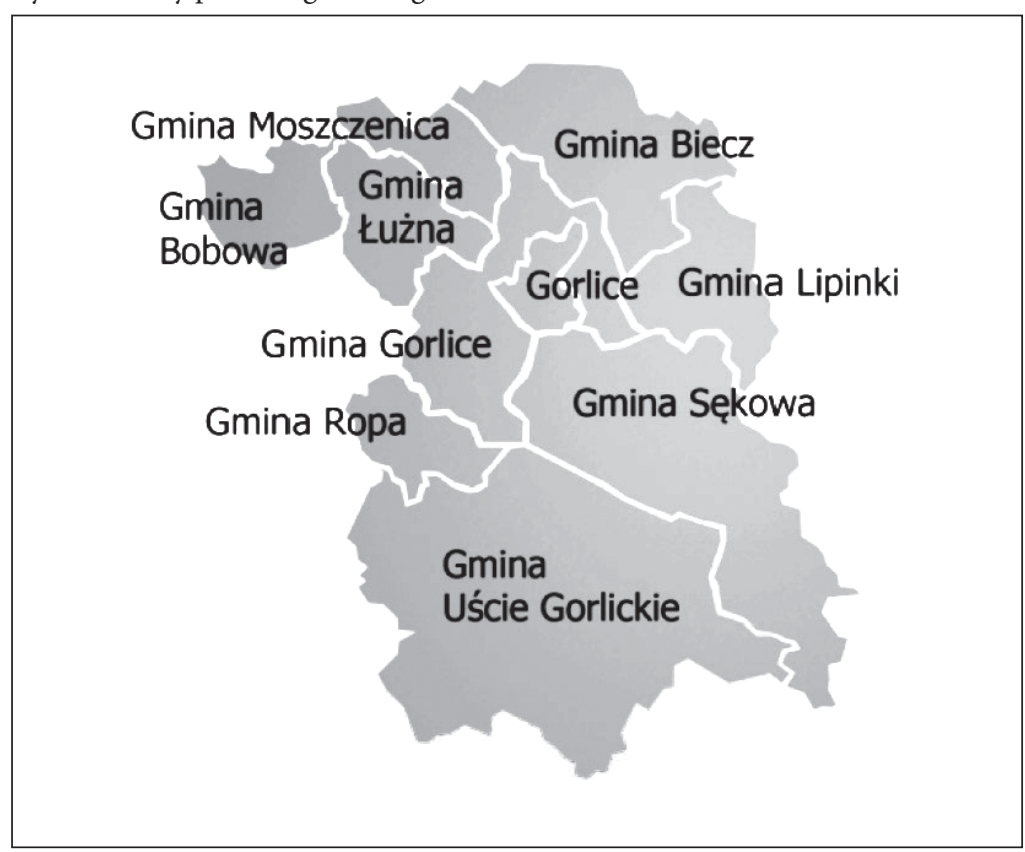

Źródło: http://zasoby-ludzkie.wup-krakow.pl/powiat-6-powiat_gorlicki.html (data dostępu: 2017, 1 września) 
Ryc. 3. Gminy powiatu limanowskiego

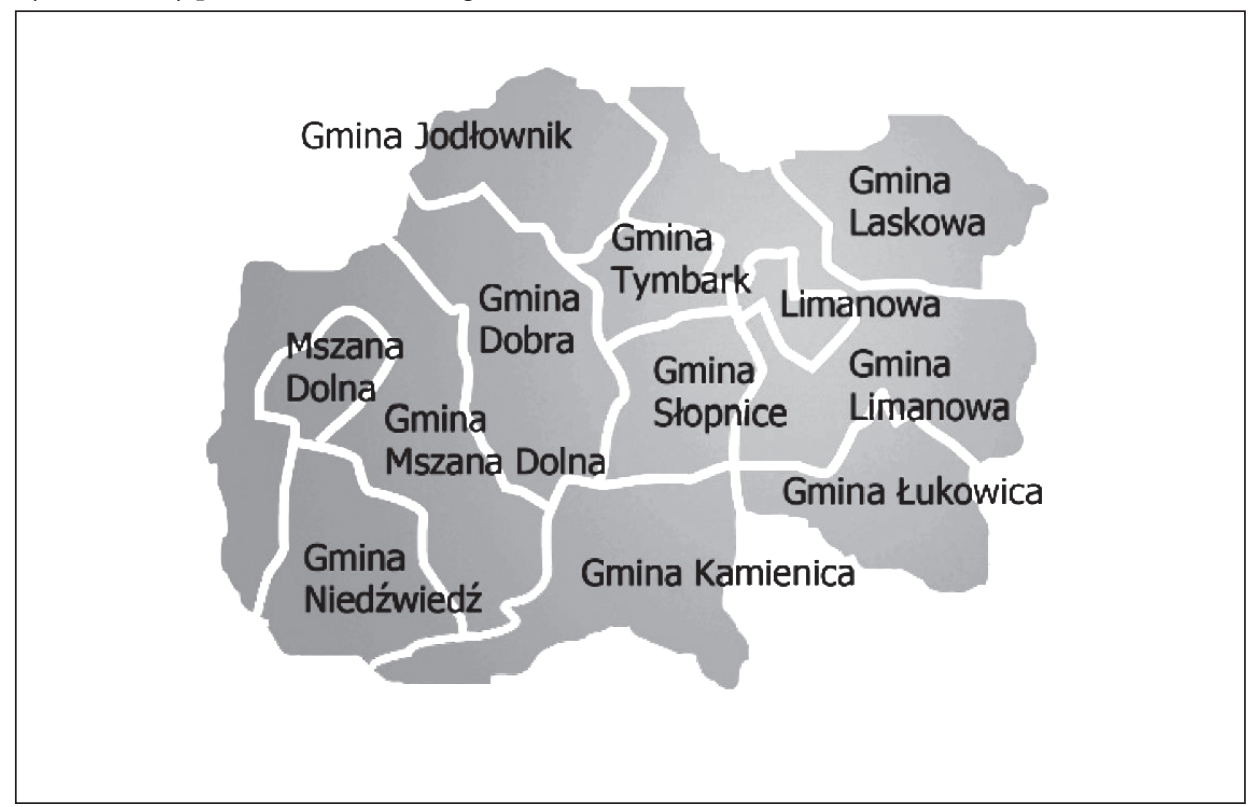

Źródło: http://www.rdr.ilimanowa.pl/index.php/tworcy-ludowi-ginace-zawody/gmina-slopnice (data dostępu: 2017, 1 września)

Ryc. 4. Gminy powiatu nowosądeckiego

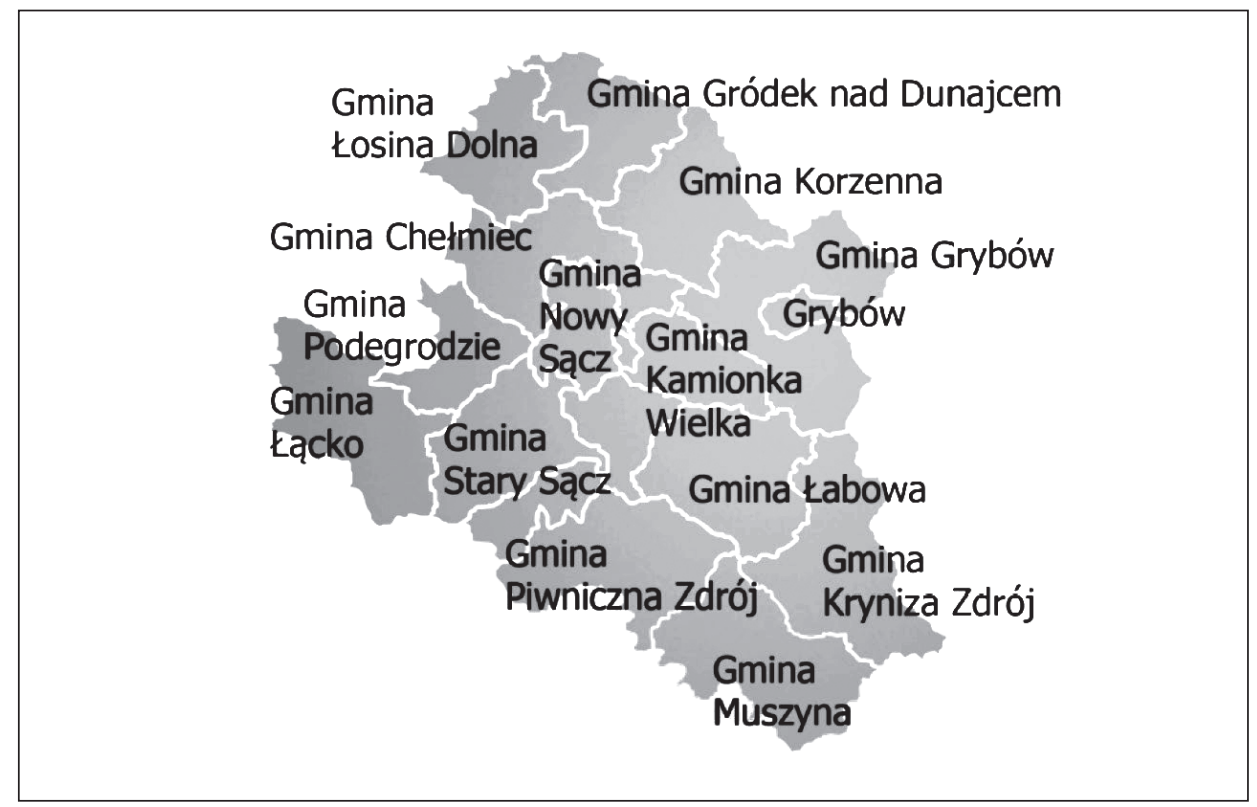

Źródło: https://www.bing.com/images/search?view=detailV2\&ccid=WLhyeE\%2bk\&id=F64537956E64978A22 7D448381C45CA17F56A467\&thid=OIP.WLhyeE-kSSxHAK AcEYXnwHaF3\&mediaurl=http\%3a\%2f\%2fzaso by-ludzkie.wup (data dostępu: 2017, 1 września) 
Tab. 1. Gminy subregionu sądeckiego

\begin{tabular}{|c|c|c|c|c|c|}
\hline Lp. & Powiat & Gmina & $\begin{array}{c}\text { Liczba } \\
\text { ludności }\end{array}$ & Powierzchnia (ha) & Status gminy \\
\hline 1. & \multirow{10}{*}{ 兑 } & Gorlice (miasto) & 27950 & 2353 & miejska \\
\hline 2. & & Gorlice & 17182 & 10285 & wiejska \\
\hline 3. & & Biecz & 16937 & 9825 & miejsko-wiejska \\
\hline 4. & & Bobowa & 9722 & 4977 & miejsko-wiejska \\
\hline 5. & & Łużna & 8409 & 5627 & wiejska \\
\hline 6. & & Uście gorlickie & 6828 & 28780 & wiejska \\
\hline 7. & & Lipinki & 6774 & 6646 & wiejska \\
\hline 8. & & Ropa & 5380 & 4911 & wiejska \\
\hline 9. & & Sękowa & 4990 & 19480 & wiejska \\
\hline 10. & & Moszczenica & 4900 & 3762 & wiejska \\
\hline 11. & \multirow{12}{*}{ 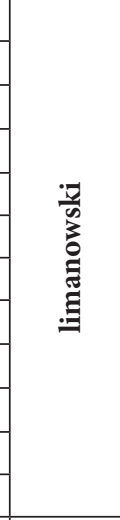 } & Limanowa & 24883 & 15223 & wiejska \\
\hline 12. & & Mszana Dolna & 17500 & 17002 & wiejska \\
\hline 13. & & Limanowa (miasto) & 15124 & 1870 & miejska \\
\hline 14. & & Dobra & 9914 & 10991 & wiejska \\
\hline 15. & & Łukowica & 9869 & 6965 & wiejska \\
\hline 16. & & Jodłownik & 8534 & 7219 & wiejska \\
\hline 17. & & \begin{tabular}{|l|} 
Laskowa \\
\end{tabular} & 8029 & 7248 & wiejska \\
\hline 18. & & Mszana Dolna (miasto) & 7936 & 2710 & miejska \\
\hline 19. & & Kamienica & 7792 & 9518 & wiejska \\
\hline 20. & & Niedźwiedź & 7275 & 7422 & wiejska \\
\hline 21. & & Słopnice & 6573 & 5685 & wiejska \\
\hline 22. & & Tymbark & 6507 & 3270 & wiejska \\
\hline 23. & \multirow{16}{*}{ 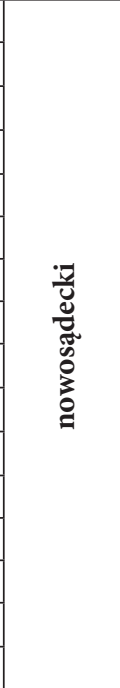 } & Chełmiec & 27889 & 11197 & wiejska \\
\hline 24. & & Grybów & 24881 & 8819 & wiejska \\
\hline 25. & & Stary Sącz & 23491 & 10088 & miejsko-wiejska \\
\hline 26. & & Krynica-Zdrój & 16843 & 14513 & miejsko-wiejska \\
\hline 27. & & Łącko & 16226 & 13295 & wiejska \\
\hline 28. & & Korzenna & 14293 & 10695 & wiejska \\
\hline 29. & & Podegrodzie & 12881 & 6473 & wiejska \\
\hline 30. & & Muszyna & 11657 & 14144 & miejsko-wiejska \\
\hline 31. & & Łososina Dolna & 10812 & 8476 & wiejska \\
\hline 32. & & Piwniczna-Zdrój & 10666 & 12646 & miejsko-wiejska \\
\hline 33. & & Kamionka Wielka & 10201 & 6498 & wiejska \\
\hline 34. & & Gródek n/Dunajcem & 9199 & 8819 & wiejska \\
\hline 35. & & Nawojowa & 8537 & 5021 & wiejska \\
\hline 36. & & Grybów (miasto) & 6066 & 1695 & miejska \\
\hline 37. & & Łabowa & 5933 & 11915 & wiejska \\
\hline 38. & & Rytro & 3845 & 4190 & wiejska \\
\hline 39. & & Nowy Sącz & 83829 & 5758 & $\begin{array}{l}\text { miasto na prawach } \\
\text { powiatu }\end{array}$ \\
\hline
\end{tabular}

Źródło: opracowanie własne na podstawie danych z BDL 
Zróżnicowanie poziomu pozarolniczej przedsiębiorczości indywidualnej w gminach subregionu sądeckiego

Przy analizie poziomu pozarolniczej przedsiębiorczości indywidualnej poza liczbą zarejestrowanych osób fizycznych prowadzących pozarolniczą działalność gospodarczą istotne znaczenie mają dwie grupy cech, dotyczące liczby nowo zarejestrowanych oraz wyrejestrowanych osób fizycznych prowadzących pozarolniczą działalność gospodarczą.

W celu uzyskania danych na temat tzw. demografii przedsiębiorstw zestawiono dane dotyczące rejestrowania i wyrejestrowywania firm osób fizycznych prowadzących pozarolniczą działalność gospodarczą w gminach subregionu sądeckiego. W analizowanym okresie w większości gmin subregionu sądeckiego liczba nowo zarejestrowanych firm przekracza liczbę firm wyrejestrowanych. Odwołując się do słownictwa demografii przedsiębiorstw, więcej firm rodzi się, niż umiera. Należy zwrócić uwagę, że w niektórych jednostkach, np. w Gorlicach (miasto) czy Nowym Sączu, liczba firm nowo zarejestrowanych i wyrejestrowanych osiągała zbliżony poziom. Może to oznaczać, że w niektórych jednostkach, podobnie jak w przypadku szerzej rozumianego poziomu przedsiębiorczości, możemy mówić o występowaniu tzw. stanu nasycenia (por. Dorocki, Sołtys, 2016).

Rycina 5 przedstawia graficzną ilustrację poziomu nowo zarejestrowanych oraz wyrejestrowanych firm osób fizycznych prowadzących pozarolniczą działalność gospodarczą w rejestrze REGON na 1000 osób w gminach subregionu sądeckiego w roku 2012, a rycina 6 - w 2016.

Istotne znaczenie mają wskaźniki obrazujące nasilenie procesu rejestrowania i wyrejestrowywania firm osób fizycznych prowadzących pozarolniczą działalność gospodarczą. W tym celu obliczone zostały wskaźniki intensywności nowo rejestrowanych i wyrejestrowywanych firm osób fizycznych prowadzących pozarolniczą działalność gospodarczą oraz wskaźnik względnej intensywności rejestrowania i wyrejestrowywania tych firm (por. Kudłacz, Reśko, 2006)

Ryc. 5. Liczba osób fizycznych prowadzących pozarolniczą działalność gospodarczą nowo zarejestrowanych i wyrejestrowanych w rejestrze REGON w gminach subregionu sądeckiego w roku 2012 na 1000 osób

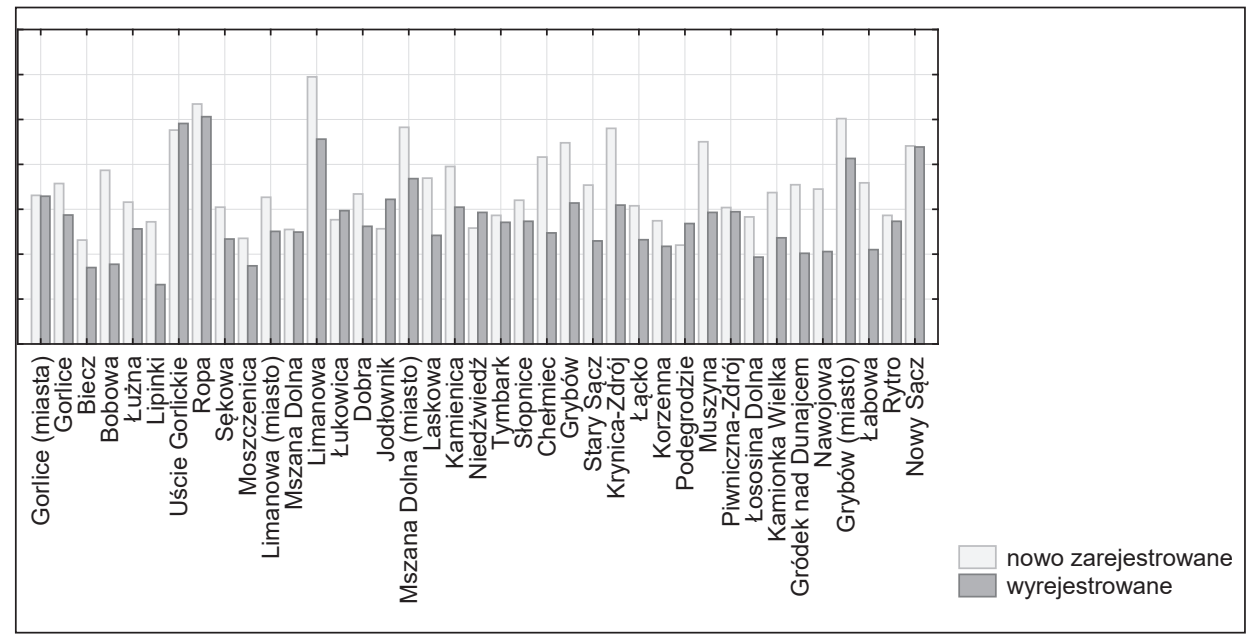

Źródło: opracowanie własne na podstawie danych z BDL 
Ryc. 6. Liczba osób fizycznych prowadzących pozarolniczą działalność gospodarczą nowo zarejestrowanych i wyrejestrowanych w rejestrze REGON w gminach subregionu sądeckiego w roku 2016 na 1000 osób

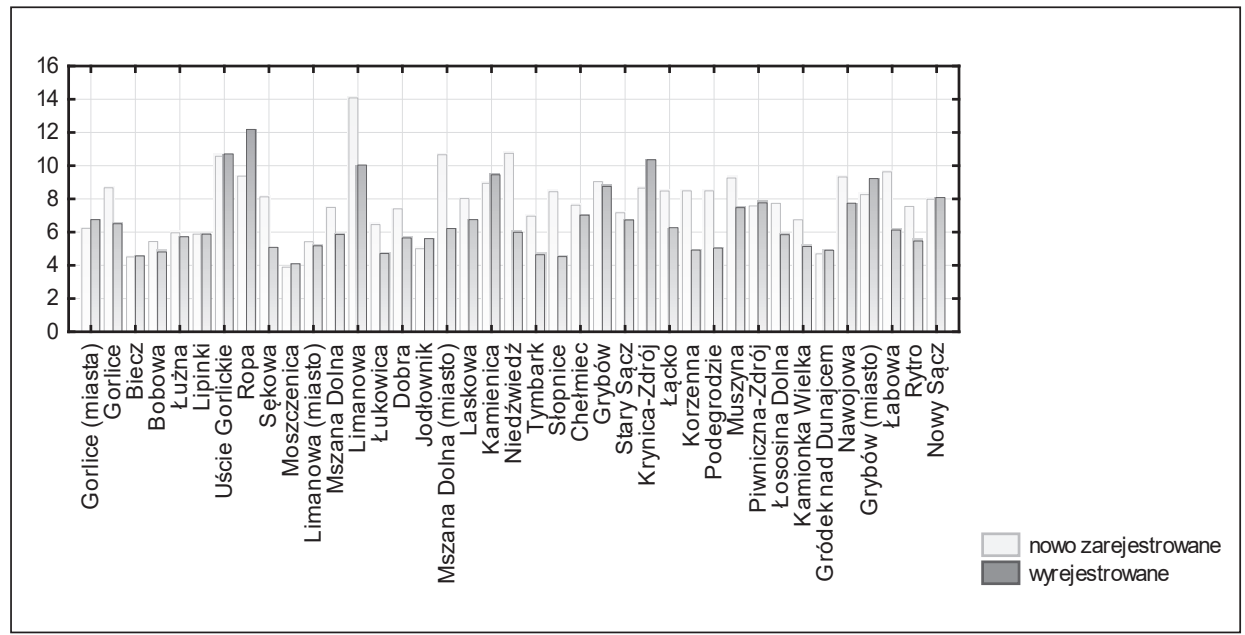

Źródło: opracowanie własne na podstawie danych z BDL

Wyliczane wskaźniki przybierają postać:

$$
\begin{gathered}
\mathrm{kn}_{\mathrm{ij}}=\frac{\mathrm{N}_{\mathrm{ij}}}{\mathrm{Y}_{\mathrm{ij}}} \\
\mathrm{kl}_{\mathrm{ij}}=\frac{\mathrm{L}_{\mathrm{ij}}}{\mathrm{Y}_{\mathrm{ij}}} \\
\mathrm{w}_{\mathrm{ij}}=\frac{\mathrm{N}_{\mathrm{ij}}}{\mathrm{N}_{\mathrm{ij}}+\mathrm{L}_{\mathrm{ij}}}
\end{gathered}
$$

Przyjęte oznaczenia:

$\mathrm{N}_{\mathrm{ij}}$ - liczba nowo zarejestrowanych firm osób fizycznych prowadzących pozarolniczą działalność gospodarczą j - tej grupy w i - tej jednostce terytorialnej łącznie w latach 2012-2016

$\mathrm{L}_{\mathrm{ij}}$ - liczba wyrejestrowanych firm osób fizycznych prowadzących pozarolniczą działalność gospodarczą j - tej grupy w i - tej jednostce terytorialnej łącznie w latach 2012-2016 $\mathrm{Y}_{\mathrm{ij}}$ - liczba zarejestrowanych firm osób fizycznych prowadzących pozarolniczą działalność gospodarczą j - tej grupy w i - tej jednostce terytorialnej łącznie w latach 2012-2016 $\mathrm{kn}_{\mathrm{ij}}$ - wskaźnik intensywności nowo zarejestrowanych firm osób fizycznych prowadzących pozarolniczą działalność gospodarczą j - tej grupy w i - tej jednostce terytorialnej łącznie w latach 2012-2016 
$\mathrm{kl}_{\mathrm{ij}}$ - wskaźnik intensywności wyrejestrowanych firm osób fizycznych prowadzących pozarolniczą działalność gospodarczą j - tej grupy w i - tej jednostce terytorialnej łącznie w latach 2012-2016

$\mathrm{w}_{\mathrm{ij}}$ - wskaźnik względnej intensywności rejestrowania i wyrejestrowywania firm osób fizycznych prowadzących pozarolniczą działalność gospodarczą j - tej grupy w i - tej jednostce terytorialnej łącznie w latach 2012-2016

Interpretacja wskaźnika względnej intensywności rejestrowania i wyrejestrowywania podmiotów gospodarczych przedstawia się następująco:

$\mathrm{w}_{\mathrm{ij}} \sim 0,5$ - zbliżona intensywność rejestrowania i wyrejestrowywania firm

$\mathrm{w}_{\mathrm{ij}}<0,5$ - większa intensywność wyrejestrowywania niż rejestrowania firm

$\mathrm{w}_{\mathrm{ij}}>0,5$ - większa intensywność rejestrowania niż wyrejestrowywania firm

$\mathrm{w}_{\mathrm{ij}}=0$ - nie zarejestrowano żadnego nowego podmiotu

$\mathrm{w}_{\mathrm{ij}}=1-\dot{z}$ aden podmiot nie został wyrejestrowany

Tab. 2.Wskaźniki intensywności nowo zarejestrowanych i wyrejestrowywanych firm osób fizycznych prowadzących pozarolniczą działalność gospodarczą oraz wskaźnik względnej intensywności rejestrowania i wyrejestrowywania firm

\begin{tabular}{|c|l|l|l|l|l|}
\hline Lp. & \multicolumn{1}{|c|}{ Powiat } & \multicolumn{1}{c|}{ Gmina } & knij & klij & wij \\
\hline 1. & gorlicki & Gorlice (1) & 0,10 & 0,10 & 0,49 \\
\hline 2. & & Gorlice (2) & 0,12 & 0,10 & 0,56 \\
\hline 3. & & Biecz (3) & 0,12 & 0,09 & 0,57 \\
\hline 4. & & Bobowa (3) & 0,15 & 0,12 & 0,55 \\
\hline 5. & & Lużna (2) & 0,15 & 0,12 & 0,56 \\
\hline 6. & & Uście Gorlickie (2) & 0,13 & 0,14 & 0,48 \\
\hline 7. & & Lipinki (2) & 0,13 & 0,10 & 0,55 \\
\hline 8. & & Ropa (2) & 0,12 & 0,12 & 0,50 \\
\hline 9. & & Sękowa (2) & 0,13 & 0,10 & 0,58 \\
\hline 10. & & Moszczenica (2) & 0,14 & 0,12 & 0,54 \\
\hline 11. & limanowski & Limanowa (2) & 0,15 & 0,11 & 0,58 \\
\hline 12. & & Mszana Dolna (2) & 0,12 & 0,09 & 0,56 \\
\hline 13. & & Limanowa (1) & 0,11 & 0,10 & 0,53 \\
\hline 14. & & Dobra (2) & 0,14 & 0,12 & 0,55 \\
\hline 15. & & Lukowica (2) & 0,14 & 0,12 & 0,55 \\
\hline 16. & & Jodłownik (2) & 0,11 & 0,09 & 0,54 \\
\hline 17. & & Laskowa (2) & 0,14 & 0,10 & 0,58 \\
\hline 18. & & Mszana Dolna (1) & 0,12 & 0,09 & 0,57 \\
\hline 19. & & Kamienica (2) & 0,16 & 0,13 & 0,56 \\
\hline 20. & & Niedźwiedź (2) & 0,16 & 0,11 & 0,59 \\
\hline 21. & & Słopnice (2) & 0,13 & 0,09 & 0,59 \\
\hline 22. & & Tymbark (2) & 0,11 & 0,09 & 0,55 \\
\hline
\end{tabular}




\begin{tabular}{|c|c|c|c|c|c|}
\hline 23. & nowosądecki & Chełmiec (2) & 0,13 & 0,10 & 0,57 \\
\hline 24. & & Grybów (2) & 0,17 & 0,14 & 0,53 \\
\hline 25. & & Stary Sącz (3) & 0,12 & 0,10 & 0,55 \\
\hline 26. & & Krynica-Zdrój (3) & 0,10 & 0,10 & 0,50 \\
\hline 27. & & Łącko (2) & 0,14 & 0,11 & 0,57 \\
\hline 28. & & Korzenna (2) & 0,16 & 0,11 & 0,60 \\
\hline 29. & & Podegrodzie (2) & 0,15 & 0,10 & 0,58 \\
\hline 30. & & Muszyna (3) & 0,13 & 0,11 & 0,54 \\
\hline 31. & & Łososina Dolna (2) & 0,13 & 0,09 & 0,60 \\
\hline 32. & & Piwniczna-Zdrój (3) & 0,11 & 0,09 & 0,53 \\
\hline 33. & & Kamionka Wielka (2) & 0,16 & 0,10 & 0,60 \\
\hline 34. & & \begin{tabular}{|l} 
Gródek nad \\
Dunajcem (2) \\
\end{tabular} & 0,14 & 0,10 & 0,57 \\
\hline 35. & & Nawojowa (2) & 0,16 & 0,11 & 0,58 \\
\hline 36. & & Grybów (1) & 0,15 & 0,15 & 0,51 \\
\hline 37. & & Łabowa (2) & 0,17 & 0,12 & 0,59 \\
\hline 38. & & Rytro (2) & 0,16 & 0,10 & 0,61 \\
\hline 39. & & Nowy Sącz (1) & 0,10 & 0,10 & 0,50 \\
\hline
\end{tabular}

Źródło: opracowanie własne na podstawie danych z BDL

Analiza wyników wskaźnika intensywności nowo zarejestrowanych firm osób fizycznych prowadzących pozarolniczą działalność gospodarczą wykazała, że wartości mieszczą się w przedziale od 0,10 do 0,17 . Najniższą intensywność nowo zarejestrowanych firm zauważono w Nowym Sączu, Gorlicach (miasto) oraz w Krynicy-Zdroju, natomiast najwyższą w gminie wiejskiej Grybów. Wartości wskaźników intensywności wyrejestrowanych firm osób fizycznych prowadzących pozarolniczą działalność gospodarczą mieszczą się w przedziale od 0,09 do 0,15. Najwyższa intensywność wyrejestrowywanych firm w badanym okresie wystąpiła w gminie miejskiej Grybów. Natomiast analiza wskaźników względnej intensywności rejestrowania i wyrejestrowywania firm osób fizycznych prowadzących pozarolniczą działalność gospodarczą wskazuje, że aż w przypadku 34 jednostek wynik był wyższy od 0,5, co oznacza większą intensywność rejestrowania niż wyrejestrowywania firm. Tylko w przypadku 2 jednostek wynik był niższy od 0,5 (tj. wystąpiła większa intensywność wyrejestrowywania niż rejestrowania firm), a w przypadku 3 jednostek (tj. Nowego Sącza, Krynicy-Zdroju i Ropy) wynik wyniósł 0,5, tzn. wystąpiła zbliżona intensywność rejestrowania i wyrejestrowywania firm.

Do określenia poziomu pozarolniczej przedsiębiorczości indywidualnej wykorzystano dane dotyczące liczby osób fizycznych prowadzących pozarolniczą działalność gospodarczą, zarejestrowanych w rejestrze REGON. Wyliczane wskaźniki przybierają postać:

$$
P_{i j}=\frac{Y_{i j}}{m_{i j}} \times 1000
$$


Przyjęte oznaczenia:

$\mathrm{P}_{\mathrm{ij}}$ - poziom pozarolniczej przedsiębiorczości indywidualne $\mathrm{j}$ - tej grupy $\mathrm{w} \mathrm{i}$ - tej jednostce terytorialnej

$\mathrm{Y}_{\mathrm{ij}}$ - liczba zarejestrowanych firm osób fizycznych prowadzących pozarolniczą działalność gospodarczą j - tej grupy w i - tej jednostce terytorialnej

$\mathrm{m}_{\mathrm{ij}}$ - liczba mieszkańców j - tej grupy w i - tej jednostce terytorialnej

Poziom pozarolniczej przedsiębiorczości indywidualnej w gminach subregionu sądeckiego ustalono na podstawie danych pochodzących z BDL i przedstawiono w tabeli 3.

Tab. 3. Poziom pozarolniczej przedsiębiorczości indywidualnej w gminach subregionu sądeckiego

\begin{tabular}{|c|c|c|c|c|c|c|c|}
\hline \multirow{2}{*}{ Lp. } & \multirow{2}{*}{ Powiat } & \multirow{2}{*}{ Gmina } & \multicolumn{5}{|c|}{ Pozarolnicza przedsiębiorczość indywidualna } \\
\hline & & & 2012 & 2013 & 2014 & 2015 & 2016 \\
\hline 1. & gorlicki & Gorlice (miasto) & 66,4 & 67,1 & 66,0 & 65,2 & 64,4 \\
\hline 2. & & Gorlice & 58,4 & 59,8 & 61,1 & 63,6 & 65,4 \\
\hline 3. & & Biecz & 38,1 & 40,6 & 41,3 & 43,4 & 43,4 \\
\hline 4. & & Bobowa & 40,4 & 41,3 & 41,7 & 40,7 & 41,2 \\
\hline 5. & & Łużna & 39,3 & 41,5 & 41,5 & 42,5 & 42,2 \\
\hline 6. & & Uście Gorlickie & 76,4 & 78,1 & 70,5 & 68,3 & 67,5 \\
\hline 7. & & Lipinki & 42,2 & 44,3 & 43,9 & 43,8 & 43,5 \\
\hline 8. & & Ropa & 84,2 & 86,1 & 86,0 & 88,7 & 84,7 \\
\hline 9. & & Sękowa & 49,8 & 52,8 & 52,5 & 54,2 & 56,7 \\
\hline 10. & & Moszczenica & 33,0 & 35,1 & 35,6 & 37,0 & 36,9 \\
\hline 11. & limanowski & Limanowa & 50,7 & 51,9 & 55,2 & 57,2 & 59,5 \\
\hline 12. & & Mszana Dolna & 56,9 & 57,7 & 59,8 & 62,5 & 63,8 \\
\hline 13. & & Limanowa (miasto) & 83,9 & 82,5 & 84,6 & 84,2 & 84,1 \\
\hline 14. & & Dobra & 51,5 & 50,6 & 51,0 & 54,6 & 56,1 \\
\hline 15. & & Łukowica & 42,8 & 43,8 & 43,4 & 45,6 & 48,0 \\
\hline 16. & & Jodłownik & 51,1 & 51,3 & 54,1 & 54,7 & 53,3 \\
\hline 17. & & Laskowa & 50,3 & 50,0 & 52,9 & 55,7 & 56,5 \\
\hline 18. & & \begin{tabular}{|l|}
$\begin{array}{l}\text { Mszana Dolna } \\
\text { (miasto) }\end{array}$ \\
\end{tabular} & 77,2 & 76,9 & 80,6 & 81,5 & 84,8 \\
\hline 19. & & Kamienica & 51,0 & 54,2 & 57,7 & 59,1 & 58,7 \\
\hline 20. & & Niedźwiedź & 49,1 & 51,9 & 54,3 & 57,9 & 61,3 \\
\hline 21. & & Słopnice & 53,4 & 54,9 & 57,0 & 58,6 & 60,5 \\
\hline 22. & & Tymbark & 58,8 & 60,4 & 61,7 & 60,9 & 62,3 \\
\hline 23. & nowosądecki & Chełmiec & 61,6 & 64,6 & 64,3 & 65,8 & 65,3 \\
\hline 24. & & Grybów & 52,0 & 51,8 & 51,5 & 53,1 & 52,8 \\
\hline 25. & & Stary Sącz & 60,4 & 61,1 & 62,4 & 63,8 & 63,9 \\
\hline 26. & & Krynica-Zdrój & 90,0 & 89,3 & 89,1 & 88,1 & 85,7 \\
\hline 27. & & Łącko & 48,9 & 50,0 & 52,8 & 53,1 & 54,8 \\
\hline 28. & & Korzenna & 40,7 & 43,3 & 44,0 & 46,5 & 49,5 \\
\hline 29. & & Podegrodzie & 40,2 & 41,7 & 43,1 & 45,5 & 48,2 \\
\hline 30. & & Muszyna & 67,3 & 67,6 & 69,5 & 69,7 & 71,5 \\
\hline
\end{tabular}




\begin{tabular}{|l|l|l|l|l|l|l|l|}
\hline 31. & & Łososina Dolna & 48,4 & 50,7 & 54,1 & 55,5 & 56,6 \\
\hline 32. & & Piwniczna-Zdrój & 68,6 & 69,9 & 72,6 & 72,1 & 71,6 \\
\hline 33. & & Kamionka Wielka & 44,9 & 47,7 & 49,1 & 52,9 & 54,1 \\
\hline 34. & & Gródek n/Dunajcem & 39,1 & 41,6 & 41,5 & 42,0 & 42,2 \\
\hline 35. & Nawojowa & 47,7 & 49,5 & 52,0 & 54,1 & 54,8 \\
\hline 36. & & Grybów (miasto) & 57,3 & 59,2 & 58,9 & 58,3 & 57,3 \\
\hline 37. & Labowa & 44,8 & 47,9 & 47,5 & 49,1 & 52,1 \\
\hline 38. & & 43,5 & 46,1 & 50,1 & 55,2 & 57,2 \\
\hline 39. & Rytro & 82,0 & 81,6 & 80,9 & 81,2 & 81,0 \\
\hline
\end{tabular}

Źródło: opracowanie własne na podstawie danych BDL

Graficzną ilustrację poziomu pozarolniczej przedsiębiorczości indywidualnej w gminach subregionu sądeckiego od 2012 do 2016 roku zaprezentowano na rycinie 7.

Na podstawie powyższego wykresu można stwierdzić, że na badanym obszarze występują gminy, w których poziom pozarolniczej przedsiębiorczości indywidualnej jest znacząco wyższy od średniego oraz znacząco niższy od średniego. Natomiast w przypadku zróżnicowania poziomu w poszczególnych latach dla danych jednostek - wahania są nieznaczne.

Ryc. 7. Poziom pozarolniczej przedsiębiorczości indywidualnej w gminach subregionu sądeckiego w latach 2012-2016

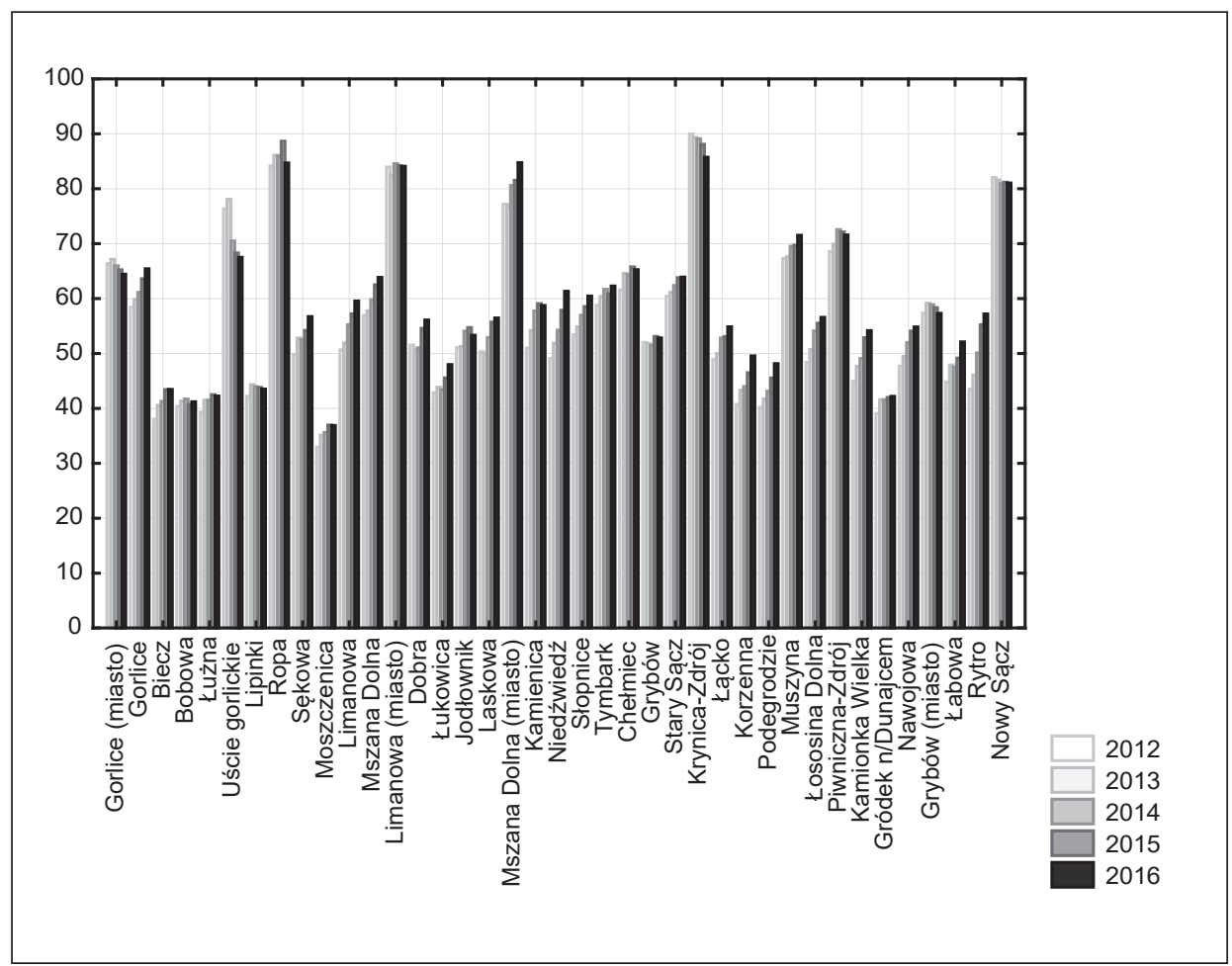

Źródło: opracowanie własne na podstawie danych z BDL 
Ryc. 8. Średnie wartości poziomu pozarolniczej przedsiębiorczości indywidualnej w gminach subregionu sądeckiego w latach 2012-2016

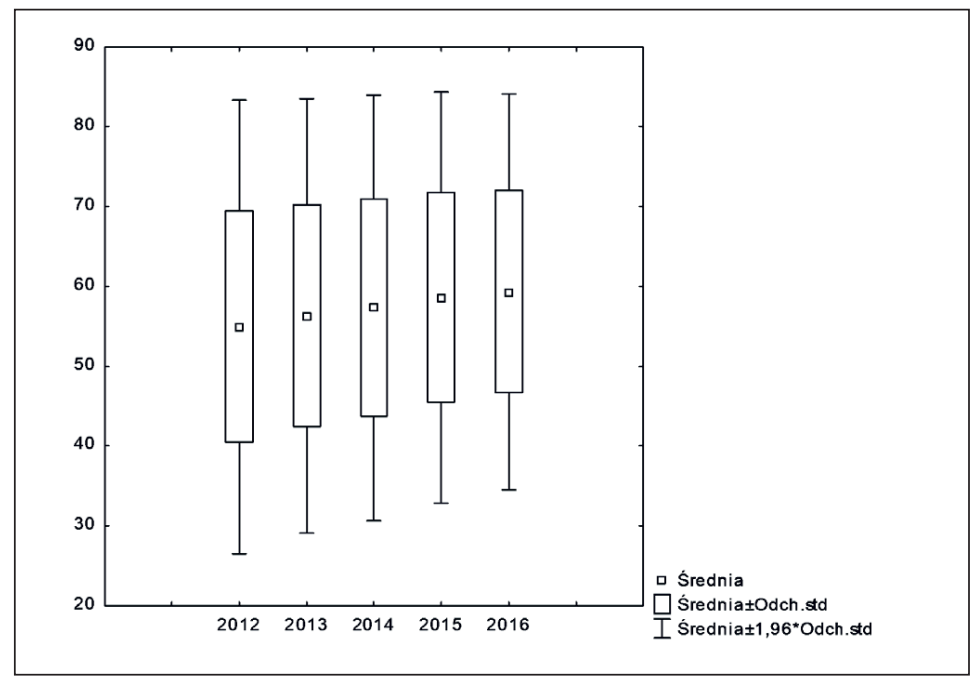

Źródło: opracowanie własne na podstawie danych z BDL

Na rycinie 8 przedstawiono średnie wartości poziomu pozarolniczej przedsiębiorczości indywidualnej w poszczególnych latach badanego okresu.

Dla każdego $\mathrm{z}$ analizowanych lat ustalono trzy poziomy pozarolniczej działalności indywidualnej: wysoki (powyżej średniej arytmetycznej powiększonej o odchylenie standardowe), średni (średnia arytmetyczna +/- odchylenie standardowe) oraz niski (poniżej średniej arytmetycznej pomniejszonej o odchylenie standardowe). Wyniki zaprezentowano w tabeli 4.

Tab. 4. Wysoki, średni i niski poziom pozarolniczej przedsiębiorczości indywidualnej w gminach subregionu sądeckiego w 2012 i 2016 roku

\begin{tabular}{|c|c|c|c|c|c|c|}
\hline Poziom & Lp. & Jednostka & $\begin{array}{c}\text { Rok } \\
2012 \\
\end{array}$ & Lp. & Jednostka & $\begin{array}{l}\text { Rok } \\
2016 \\
\end{array}$ \\
\hline \multirow{6}{*}{$\begin{array}{l}\text { 흥 } \\
0 \\
3 \\
3\end{array}$} & 1. & Krynica-Zdrój (3) & 90,0 & 1. & Krynica-Zdrój (3) & 85.7 \\
\hline & 2. & Ropa (2) & 84,2 & 2. & Mszana Dolna (1) & 84,8 \\
\hline & 3. & Limanowa (1) & 83,9 & 3. & Ropa (2) & 84,7 \\
\hline & 4. & Nowy Sącz (1) & 82,0 & 4. & Limanowa (1) & 84,1 \\
\hline & 5. & Mszana Dolna (1) & 77,2 & \multirow[t]{2}{*}{5.} & \multirow[t]{2}{*}{ Nowy Sącz (1) } & \multirow[t]{2}{*}{81,0} \\
\hline & 6. & Uście Gorlickie (2) & 76,4 & & & \\
\hline \multirow{9}{*}{$\begin{array}{l}\ddot{\Xi} \\
\tilde{D} \\
\dot{\nu}\end{array}$} & 7. & Piwniczna-Zdrój (3) & 68,6 & 6. & Piwniczna-Zdrój (3) & 71,6 \\
\hline & 8. & Muszyna (3) & 67,3 & 7. & Muszyna (3) & 71,5 \\
\hline & 9. & Gorlice (1) & 66,4 & 8. & Uście Gorlickie (2) & 67,5 \\
\hline & 10. & Chełmiec (2) & 61,6 & 9. & Gorlice (2) & 65,4 \\
\hline & 11. & Stary Sącz (3) & 60,4 & 10. & Chełmiec (2) & 65,3 \\
\hline & 12. & Tymbark (2) & 58,8 & 11. & Gorlice (1) & 64,4 \\
\hline & 13. & Gorlice (2) & 58,4 & 12. & Stary Sącz (3) & 63,9 \\
\hline & 14. & Grybów (1) & 57,3 & 13. & Mszana Dolna (2) & 63,8 \\
\hline & 15. & Mszana Dolna (2) & 56,9 & 14. & Tymbark (2) & 62,3 \\
\hline
\end{tabular}




\begin{tabular}{|c|c|c|c|c|c|c|}
\hline \multirow{19}{*}{ 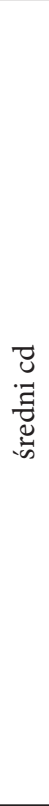 } & 16. & Słopnice (2) & 53,4 & 15. & Niedźwiedź (2) & 61,3 \\
\hline & 17. & Grybów (2) & 52,0 & 16. & Słopnice (2) & 60,5 \\
\hline & 18. & Dobra (2) & 51,5 & 17. & Limanowa (2) & 59,5 \\
\hline & 19. & Jodłownik (2) & 51,1 & 18. & Kamienica (2) & 58,7 \\
\hline & 20. & Kamienica (2) & 51,0 & 19. & Grybów (1) & 57,3 \\
\hline & 21. & Limanowa (2) & 50,7 & 20. & Rytro (2) & 57,2 \\
\hline & 22. & Laskowa (2) & 50,3 & 21. & Sękowa (2) & 56,7 \\
\hline & 23. & Sękowa (2) & 49,8 & 22. & Łososina Dolna (2) & 56,6 \\
\hline & 24. & Niedźwiedź (2) & 49,1 & 23. & Laskowa (2) & 56,5 \\
\hline & 25. & Łącko (2) & 48,9 & 24. & Dobra (2) & 56,1 \\
\hline & 26. & Łososina Dolna (2) & 48,4 & 25. & Łącko (2) & 54,8 \\
\hline & 27. & Nawojowa (2) & 47,7 & 26. & Nawojowa (2) & 54,8 \\
\hline & 28. & Kamionka Wielka (2) & 44,9 & 27. & Kamionka Wielka 2) & 54,1 \\
\hline & 29. & Łabowa (2) & 44,8 & 28. & Jodłownik (2) & 53,3 \\
\hline & 30. & Rytro (2) & 43,5 & 29. & Grybów (2) & 52,8 \\
\hline & 31. & Łukowica (2) & 42,8 & 30. & Łabowa (2) & 52,1 \\
\hline & 32. & Lipinki (2) & 42,2 & 31. & Korzenna (2) & 49,5 \\
\hline & 33. & Korzenna (2) & 40,7 & 32. & Podegrodzie (2) & 48.2 \\
\hline & & & & 33. & Łukowica (2) & 48.0 \\
\hline \multirow{6}{*}{$\frac{\sqrt[7]{n}}{\exists}$} & 34. & Bobowa (3) & 40,4 & 34 & Lpinki (2) & 43,5 \\
\hline & 35. & Podegrodzie (2) & 40,2 & 35 & Biecz (3) & 43,4 \\
\hline & 36. & Łużna (2) & 39,3 & 36 & Łużna (2) & 42,2 \\
\hline & 37. & $\begin{array}{l}\text { Gródek nad Dunajcem } \\
(2)\end{array}$ & 39,1 & 37 & $\begin{array}{l}\text { Gródek nad Dunajcem } \\
(2)\end{array}$ & 42,2 \\
\hline & 38. & Biecz 3 & 38,1 & 38 & Biecz 3 & 41,2 \\
\hline & 39. & Moszczenica (2) & 33,0 & 39 & Moszczenica (2) & 36,9 \\
\hline
\end{tabular}

Źródło: opracowanie własne na podstawie danych z BDL

Przestrzenne zróżnicowanie poziomu pozarolniczej działalności indywidualnej w gminach subregionu sądeckiego w roku 2012 i 2016 zaprezentowano na rycinach 9 i 10.

Analiza przestrzennego zróżnicowania poziomu pozarolniczej działalności indywidualnej w gminach subregionu sądeckiego pokazuje, że należy zwrócić uwagę na charakterystyczne rozmieszczenie jednostek, w których wystąpił niski poziom (gminy na granicy subregionu). Zapewne związane jest to $\mathrm{z}$ mniej korzystnym ukształtowaniem terenu, brakiem wyraźnie rozwiniętej infrastruktury, w tym turystycznej, oraz sporym oddaleniem od centrum subregionu, czyli miasta Nowy Sącz.

Poziom pozarolniczej przedsiębiorczości indywidualnej a status gminy

W kolejnym etapie badania sprawdzono, jak kształtują się średnie wartości wskaźników określających poziom pozarolniczej przedsiębiorczości indywidualnej w gminach subregionu sądeckiego, odrębnie dla gmin wiejskich, miejskich i wiejsko-miejskich. Wyniki zaprezentowano w tabeli 5. 
Ryc. 9. Przestrzenne zróżnicowanie poziomu pozarolniczej działalności indywidualnej w gminach subregionu sądeckiego w roku 2012

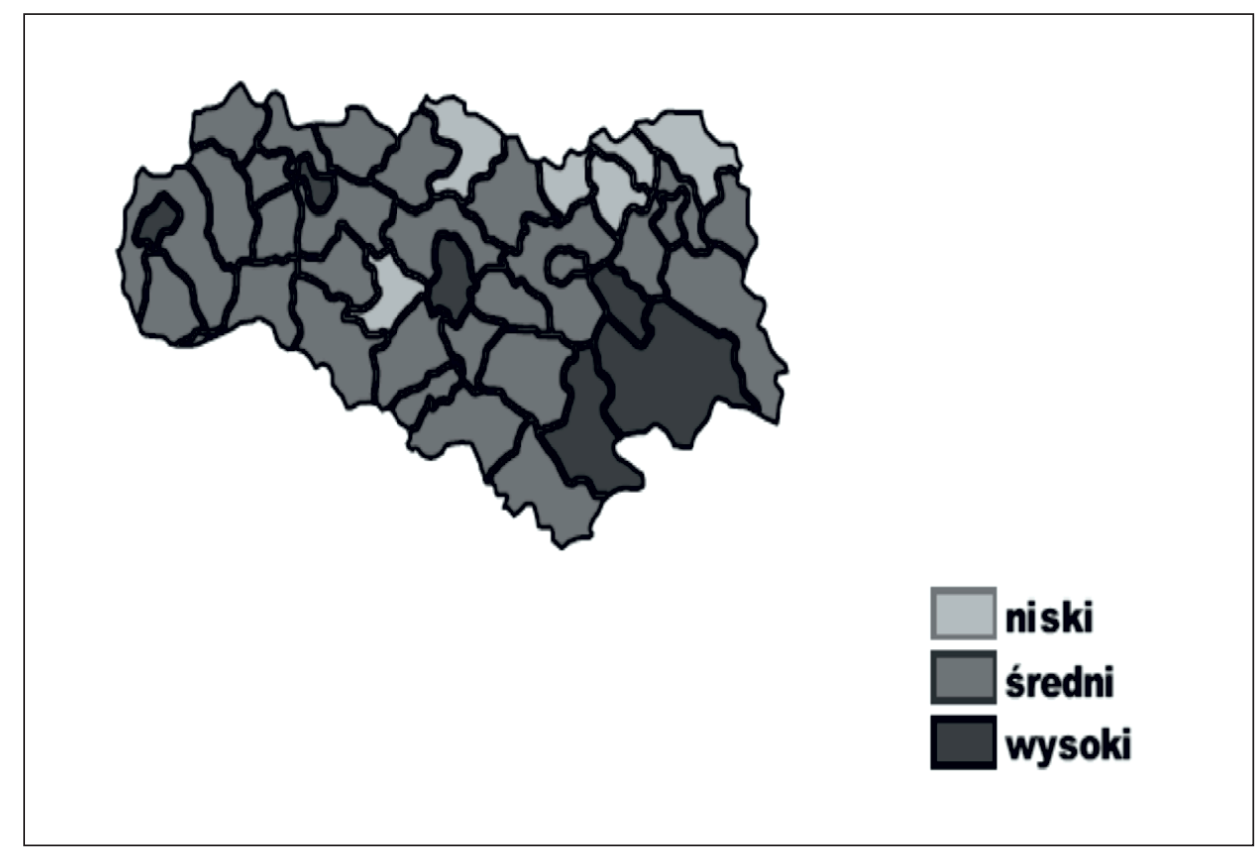

Źródło: opracowanie własne na podstawie danych z BDL

Ryc. 10. Przestrzenne zróżnicowanie poziomu pozarolniczej działalności indywidualnej w gminach subregionu sądeckiego w roku 2016

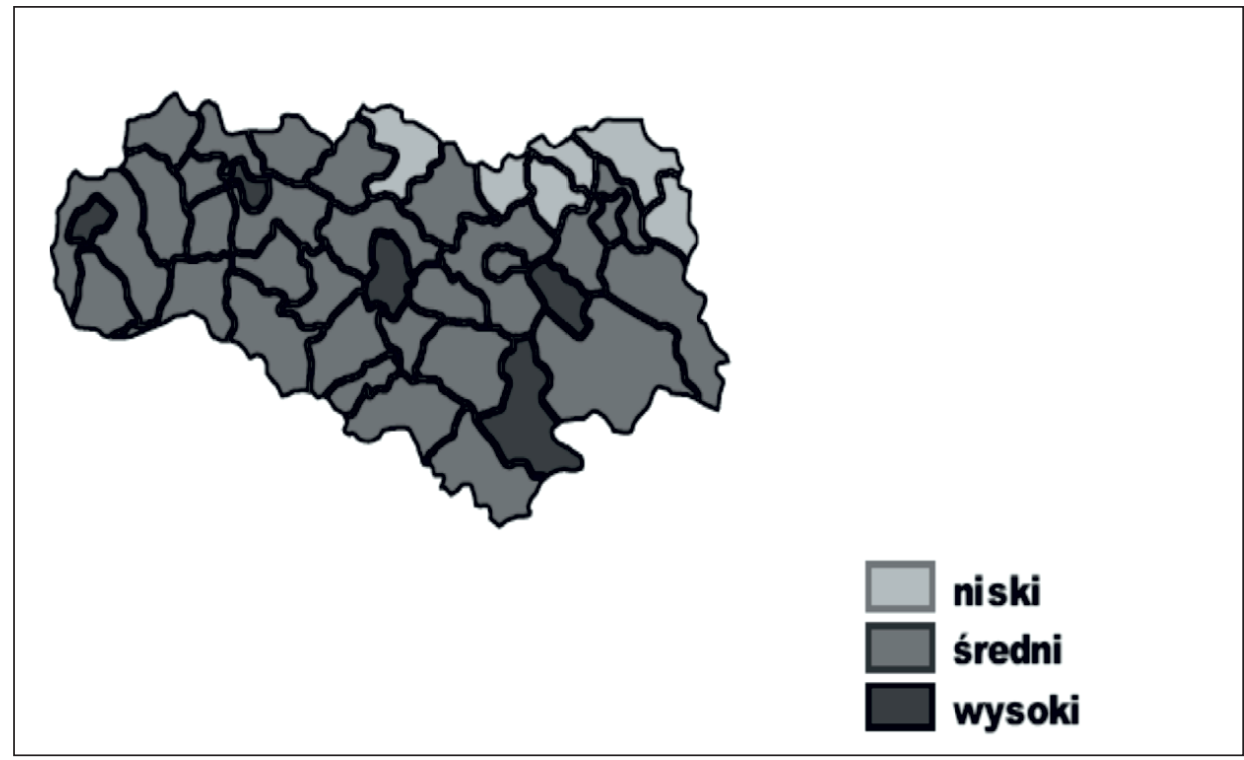

Źródło: opracowanie własne na podstawie danych z BDL 
Tab. 5. Średnie wartości poziomu pozarolniczej działalności indywidualnej ze względu na status gminy

\begin{tabular}{|c|c|c|c|}
\hline \multirow{2}{*}{ Lata } & \multicolumn{3}{|c|}{ Gminy } \\
\cline { 2 - 4 } & wiejskie & miejskie & wiejsko-miejskie \\
\hline 2012 & 50,4 & 71,2 & 60,8 \\
\hline 2013 & 52,1 & 71,4 & 61,6 \\
\hline 2014 & 53,2 & 72,5 & 62,8 \\
\hline 2015 & 54,9 & 72,3 & 63,0 \\
\hline 2016 & 55,9 & 72,6 & 62,9 \\
\hline
\end{tabular}

Źródło: opracowanie własne na podstawie danych z BDL

We wszystkich latach badanego okresu najwyższy poziom średniej wystąpił w gminach miejskich, nieco niższy w gminach wiejsko-miejskich, a najniższy w gminach wiejskich. Na podstawie tej analizy można stwierdzić, że pozarolnicza przedsiębiorczość indywidualna najlepiej rozwija się w gminach miejskich. Rozpoznanie przyczyn (poza oczywistymi, którymi wydają się być m.in. ukształtowanie terenu czy poziom rozwoju infrastruktury technicznej) powodujących, że w określonych jednostkach poziom pozarolniczej przedsiębiorczości indywidualnej jest znacząco wyższy niż w innych, może stanowić bardzo ciekawą płaszczyznę do kolejnych badań nad przedsiębiorczością w układach lokalnych.

Poziom pozarolniczej przedsiębiorczości indywidualnej a poziom bezrobocia i dochodów własnych budżetów

Do określenia związku pomiędzy poziomem pozarolniczej przedsiębiorczości indywidualnej a poziomem bezrobocia (relacja $\mathrm{nr}$ 1) oraz pomiędzy poziomem pozarolniczej przedsiębiorczości indywidualnej a dochodami własnymi budżetu (relacja nr 2) obliczono współczynniki korelacji Pearsona (Maszorek-Szymala, 2007: 56). Wyliczane wskaźniki przybierają postać:

$$
r_{x y}=\frac{\sum_{i=1}^{n}\left(x_{i}-\bar{x}\right)\left(y_{i}-\bar{y}\right)}{\left.\sqrt{\sum_{i=1}^{n}\left(x_{i}\right.}-\bar{x}\right) \sqrt{\sum_{i=1}^{n}\left(y_{i}-\bar{y}\right)}}
$$

Przyjęte oznaczenia:

$\mathrm{r}_{\mathrm{xy}}$ - współczynnik korelacji

$\mathrm{x}_{\mathrm{i}}$ - liczba osób fizycznych prowadzących pozarolniczą działalność gospodarczą na 1000 osób

i $\bar{y}-$ średnie arytmetyczne

$\mathrm{y}_{\mathrm{i}}-$ udział bezrobotnych zarejestrowanych $\mathrm{w}$ liczbie ludności w wieku produkcyjnym w danej jednostce terytorialnej (relacja nr 1) oraz dochody własne budżetu jednostki samorządu terytorialnego na 1 mieszkańca

Interpretacja współczynnika korelacji przedstawia się następująco (Góralski, 1976):

$\mathrm{r}_{\mathrm{xy}}=0$ - brak zależności

$\left|\mathrm{r}_{\mathrm{xy}}\right| \mathrm{w}$ przedziale $(0 ; 0,1)$ - zależność nikła

$\left|\mathrm{r}_{\mathrm{xy}}\right|$ w przedziale $(0,1 ; 0,3)$ - zależność słaba

$\left|\mathrm{r}_{\mathrm{xy}}\right| \mathrm{w}$ przedziale $(0,3 ; 0,5)$ - zależność przeciętna 
$\left|\mathrm{r}_{\mathrm{xy}}\right| \mathrm{w}$ przedziale $(0,5 ; 0,7)$ - zależność wysoka

$\left|\mathrm{r}_{\mathrm{xy}}\right| \mathrm{w}$ przedziale $(0,7 ; 0,9)$ - zależność bardzo wysoka

$\left|\mathrm{r}_{\mathrm{xy}}\right| \mathrm{w}$ przedziale $(0,9 ; 1)$ - zależność niemal pełna

$\left|\mathrm{r}_{\mathrm{xy}}\right|=1-$ zależność pełna

Związek pomiędzy liczbą zarejestrowanych firm osób fizycznych prowadzących pozarolniczą działalność gospodarczą na 1000 osób a udziałem bezrobotnych zarejestrowanych w liczbie ludności w wieku produkcyjnym wyniósł -0,12. Wynik wskazuje, że występuje korelacja ujemna, czyli gdy zwiększa się liczba zarejestrowanych firm osób fizycznych, to zmniejsza się udział bezrobotnych zarejestrowanych w liczbie ludności w wieku produkcyjnym. Niemniej jednak w przypadku siły korelacji wynik wskazuje na bardzo słabą zależność.

Osoby fizyczne prowadzące pozarolniczą działalność gospodarczą najczęściej opłacają podatek dochodowy, wybierając jako formę opodatkowania: ryczałt od przychodów ewidencjonowanych lub kartę podatkową albo opłacają podatek dochodowy tzw. PIT. Zarówno wpływy z karty podatkowej jak również udział w PIT stanowią dochód budżetu jednostki samorządu terytorialnego. Związek pomiędzy liczbą zarejestrowanych firm osób fizycznych prowadzących pozarolniczą działalność gospodarczą na 1000 osób a dochodami własnymi budżetu jednostki samorządu terytorialnego na 1 mieszkańca wyniósł 0,66. Wynik wskazuje, że występuje korelacja dodatnia, czyli gdy zwiększa się liczba zarejestrowanych firm osób fizycznych, to zwiększa się także poziom dochodów własnych budżetu jednostki samorządu terytorialnego na 1 mieszkańca. W przypadku siły korelacji wynik wskazuje na wysoką zależność.

\section{Wnioski}

Przedstawione wyliczenia i analizy prowadzą do kilku istotnych wniosków i spostrzeżeń związanych z poziomem pozarolniczej przedsiębiorczości indywidualnej w gminach subregionu sądeckiego:

- w większości gmin subregionu sądeckiego liczba nowo zarejestrowanych firm osób fizycznych prowadzących pozarolniczą działalność gospodarczą na 1000 osób przekracza liczbę firm wyrejestrowanych,

- w 34 z 39 jednostek objętych badaniem stwierdzono większą intensywność rejestrowania niż wyrejestrowywania firm,

- występuje znaczące zróżnicowanie przestrzenne poziomu pozarolniczej działalności indywidualnej w gminach subregionu sądeckiego,

- charakterystyczne rozmieszczenie jednostek (tj. na granicy subregionu), w których wystąpił niski poziom pozarolniczej działalności indywidualnej,

- najwyższa wartość średniej poziomu pozarolniczej działalności indywidualnej, we wszystkich latach badanego okresu, wystąpiła w gminach miejskich, nieco niższa w gminach wiejsko-miejskich, a najniższa - w gminach wiejskich,

- występuje słaba ujemna zależność pomiędzy poziomem badanego zjawiska a poziomem bezrobocia w danej gminie,

- występuje wysoka dodatnia zależność pomiędzy poziomem badanego zjawiska a poziomem dochodów własnych budżetu danej jednostki. 
Literatura

\section{References}

Dorocki, S., Sołtys, J. (2016). Wskaźnik przedsiębiorczości w jednostkach terytorialnych Polski zróżnicowanie w czasie i przestrzeni. Przedsiębiorczość - Edukacja, 12, 18-45.

Góralski, A. (1976). Metody opisu i wnioskowania statystycznego w psychologii. Warszawa: PWN.

Kuciński, K. (2010). Regionalna perspektywa przedsiębiorczości. W: K. Kuciński (red.), Przedsiębiorczość a rozwój regionalny w Polsce. Warszawa: Difin.

Kudłacz, T., Reśko, D. (2007). Przedsiębiorczość w subregionie nowosądeckim w latach 2001-2004. Zeszyty Naukowe Akademii Ekonomicznej w Krakowie, 746.

Maszorek-Szymala, A. (2007). Podstawy statystki dla studentów i nauczycieli. Kraków: Oficyna Wydawnicza „Impuls”.

Niedziółka, M. (2010). Przedsiębiorczość gminy a rozwój regionalny. W: K. Kuciński (red.), Przedsiębiorczość a rozwój regionalny w Polsce. Warszawa: Difin.

Targalski, J. (1999). Przedsiębiorczość u progu nowej dekady - scenariusz optymistyczny. W: Przedsiębiorczość a lokalny i regionalny rozwój gospodarczy. Materialy konferencji naukowej. Kraków: Wydawnictwo Akademii Ekonomicznej w Krakowie.

Natalia Jaśkiewicz, mgr, Państwowa Wyższa Szkoła Zawodowa w Nowym Sączu, Instytut Ekonomiczny. Absolwentka studiów licencjackich z zakresu ekonomii Państwowej Wyższej Szkoły Zawodowej w Nowym Sączu oraz uzupełniających studiów magisterskich z zakresu marketingu i zarządzania Uniwersytetu Ekonomicznego w Krakowie, doktorantka Uniwersytetu Ekonomicznego w Krakowie. Jej zainteresowania badawcze skupiają się wokół problematyki przedsiębiorczości w układach lokalnych i regionalnych.

Natalia Jaśkiewicz, MSc, State Higher Vocational School in Nowy Sącz, Institute of Economics. A graduate of bachelor studies in Economics at State Higher Vocational School in Nowy Sącz and supplementary MSc studies in the field of Marketing and management at Cracow University of Economics, PhD student at Cracow University of Economics. Author's research interests focus on entrepreneurship issues in local and regional co-ordinate systems.

\section{Adres/Address:}

Państwowa Wyższa Szkoła Zawodowa w Nowym Sączu

Instytut Ekonomiczny

ul. Jagiellońska 61

33-300 Nowy Sącz, Polska

e-mail: jaskiewiczn@op.pl 